\title{
ASSESSING HOUSEHOLDS' GAS AND ELECTRICITY CONSUMPTION: A CASE STUDY OF DJELFA, ALGERIA
}

\author{
Soufiane Boukarta ${ }^{1,2}$, Ewa BerezowsKa-AzZaG ${ }^{2}$ \\ ${ }^{1}$ Institut d'Architecture et d'Urbanisme (IAU), Université de Blida 1, Algeria \\ ${ }^{2}$ Ecole polytechnique d'Architecture et d'Urbanisme (EPAU), Laboratoire Ville, Urbanisme et Développement \\ Durable (VUDD). Algiers, Algeria
}

Manuscript received: March 25, 2018

Revised version: April 30, 2018

Boukarta S., Berezowska-AzZag E., 2018. Assessing households' gas and electricity consumption: Case study of Djelfa, Algeria. Quaestiones Geographicae 37(4), Bogucki Wydawnictwo Naukowe, Poznań, pp. 111-129. 11 tables, 13 figs.

AвstRAct: Households are the major energy consumer and contributor to the emission of greenhouse gases. The Algerian policy of mastering energy has improved building energy efficiency since 1994 by introducing thermal regulation (DTR). However, energy consumption is still increasing instead of decreasing, which is mainly due to occupants' behaviour which is difficult to estimate and predict. This paper explores the impact of households and housing characteristics on residential gas and electricity consumption in the 36 municipalities of the department of Djelfa (Algeria) which is located in an arid and semi-arid climate zone. This paper is based on GIS and statistical techniques. It considers the yearly gas and electricity energy consumption (2013) of the municipalities of the department of Djelfa. The method is organised in four steps: (a) a multiple linear regression is used to construct two estimative models of gas and electricity. The models have more than $93 \%$ of accuracy for both gas and electricity models; (b) estimating gas and electricity consumption for 2008 according to the developed models; (c) organisation of the census data of 2008 in five dimensions: the population distribution, household characteristics, housing type and occupancy, and finally household appliance ownership; (d) a set of sensitivity analysis is performed based on Principal Component Analysis (PCA) and Pearson's bivariate correlation and finally a path analysis is performed based on Structural Equation Model (SEM) to assess the importance of each variable. The overall impact of all these variables indicates that increasing the household size is the first factor reducing the electricity and gas consumption followed by the housing surface, density, room occupancy, and older households, while increasing the education level and appliance ownership boosts both per-capita gas and electricity consumption.

KEYWORDS: Algeria, gas consumption, electricity consumption, household characteristics, housing characteristics, density, statistical approach, GIS

Corresponding author: Soufiane Boukarta, Institut d'Architecture et d'Urbanisme (IAU), Université de Blida 1, Algeria; Ecole polytechnique d'Architecture et d'Urbanisme (EPAU), Laboratoire Ville, Urbanisme et Développement Durable (VUDD).

Algiers, Algeria, e-mail: boukarta.soufiane@univ-blida.dz

\section{Introduction}

The worldwide consumption of energy has become a crucial problem. The population is rising which leads to an increase in the energy demand and energy consumption. The priority of the world summits is given to energy saving by implementing several policies to reduce energy consumption and greenhouse gas emissions.

Since 1985 Algeria has founded the APRUE (Agence pour la Promotion et la Rationalisation dans l'Usage de l'Energie) to elaborate methods and tools to rationalise the energy demand and consumption in all the Algerian economic 
sectors. APRUE (2012) shows that housing is the biggest energy-consuming sector in Algeria with a consumption of about $41 \%$. The Algerian energy policy was established within law 99-09 which could be organised within five strategies based on Sénit (2008), Himri et al. (2009), APRUE (web site), Bouamama (2013) and Hamiche et al. (2015). The first strategy aims to train architects and engineers to be able to assess the energy demand by introducing a set of trainings and courses across universities, schools, and institutes as well. Also, APRUE and GIZ developed a project interpreted in two ways; (a) a guide-book (Giz 2015) containing different strategies aiming to reduce the energy consumption in buildings according to different climate zones. That guide was distributed for free by APRUE. This book, however, is very ambitious because it proposes a $U$ value of 0.25 to $0.5 \mathrm{w} / \mathrm{m}^{2} . \mathrm{k}$ for walls. These values are taken into consideration in industrial countries. The guide book has no power to make architects or engineers respect its rules. (b) The second way is to share the actual thermal regulations of Algeria online. The web-site is reta.cder.dz (CDER) and it contains an easy method to assess the building energy budget based on the quality of the envelope within a static method.

The second strategy is interpreted by the construction of 600 dwellings in different climate zones. The main directions of these pilot projects are to improve the insulation level of the considered buildings (Bouamama 2013).

The third strategy aims to keep consumers aware of rationalising their energy consumption. A several media spots are broadcast on radio and television. They aim to promote some directions on how to rationally use the heater and the air conditioner.

The fourth strategy is based on supporting the ownership of renewable energy tools by consumers. The government supports $50 \%$ of the use of natural gas in cars, and covers $45 \%$ of the cost of purchasing solar water heaters. By the beginning of 2016, the government helped to improve insulation in houses. Its ambition is to do so in 100,000 houses per year. This program, however, is thinly spread due to weak media support.

The fifth strategy is legislative framing in Algeria which is supported by a panoply of existing laws. For example, law number 99-09 (1999) on energy mastering, law number 02-01 (2002) on electricity and gas distribution, and law number 04-09 (2004) relate to the renewable energy promotion, and law number 14-27 on urban and architectural techniques is applicable to southern cities (JO 2017). Inter-ministerial decrees (20082009) on labeling household appliances (Aprue 2010) and the building thermal regulations DTR C3.2 (2004) and DTR C3.4 (2004).

The strategies which are supported by the government did not take into account the importance of the urban realm and the impact of households' characteristics on the energy demand and energy consumption. Countries all over the world, especially developed ones, have achieved a lot of progress in improving the energy efficiency in buildings. However, other pieces of the research highlighted (Chen 2013; Subrémon 2009) that the gap between the energy consumption of households achieved within the same theoretical energy performance can vary up to a factor of two (Dall'o et al. 2012; Beerepoot 2007). In the same lines, previous pieces of research in the US and the Netherlands showed that the characteristics of buildings accounted for only $40-54 \%$ of energy consumption (Guerra 2010; Sonderegger 1978). Therefore, it is widely recognised that the energy consumption of residential buildings is not particularly affected by building characteristics but is also influenced by household characteristics, occupants behaviour, and service systems (Haas et al. 1998; Salat et al. 2011).

The scientific literature shows that the impact of household characteristics and behaviour is relative and contrasted. In the Netherlands, Guerra (2010) states that occupants' behaviour and household characteristics significantly consume the energy use by $4.2 \%$ while the building characteristics still determine a large part $(42 \%)$ of the energy use in dwellings. Moreover, in the US, Sonderegger (1978) showed that the impact of occupants on the observed variability of the energy consumption in similar houses is about $33 \%$. To explain this large impact between studies, researchers stated that the role of occupant behaviour in energy consumption increased as well as the energy performance of buildings (Haas et al. 1998; Groot et al. 2008).

Occupants' behaviour and household characteristics which impact the energy consumption directly and indirectly are considered to be the income, occupant age, household size and 
education levels (Chen et al. 2013). Based on social, financial, energy and technical data from about 1,110 homeowners in Athens, Santamouris et al. (2007) found that the income affects energy consumption indirectly because it is linked to the household size, the envelope quality of a dwelling, the age, type and occupied area of a dwelling, the duration of heating and air conditioner ownership. In addition, the occupant's age was found to influence the energy consumption, i.e. older occupants tend to consume more energy (Chen et al. 2013).

In other studies, the density is also reported to have an impact on household energy consumption. However, its impact is relative because some research introduced a positive correlation (Steadman 1979; Hui 2001; Lariviere et al. 2009). Other studies pointed out that higher density led to a decrease in the household's energy consumption (Salat 2011; Holden, Norland 2005).

Recent studies in the residential sector in Algeria largely focus on measures to improve the building energy efficiency by improving building insulation (Ali-Toudert 2017; Derradji et al. 2017; Imessad et al. 2014; Djelloul et al. 2013). However, household characteristics and occupants' behaviour have not been covered in the literature in Algeria yet, and it is still unknown how much variation in residential energy consumption they could be accounted for.

Therefore, this study aims to investigate the impact of household, housing characteristics and density at the municipality scale for the prefecture of Djelfa in an arid and semi-arid climate zone on household gas and electricity consumption through answering this question:

Could households, housing characteristics and the density of the population explain some variation in residential gas and electricity consumption? If so, how much could they explain?

\section{Case study}

Djelfa is one of the prefectures of Algeria, which is located in the area of highlands between 34.3 degrees of latitude and 3.7 degrees of longitude. The national policy of territory planning aims to create new cities in this band to balance the demographical distribution of the population between the crowded north, and the sparsely populated south. Djelfa is composed of 36

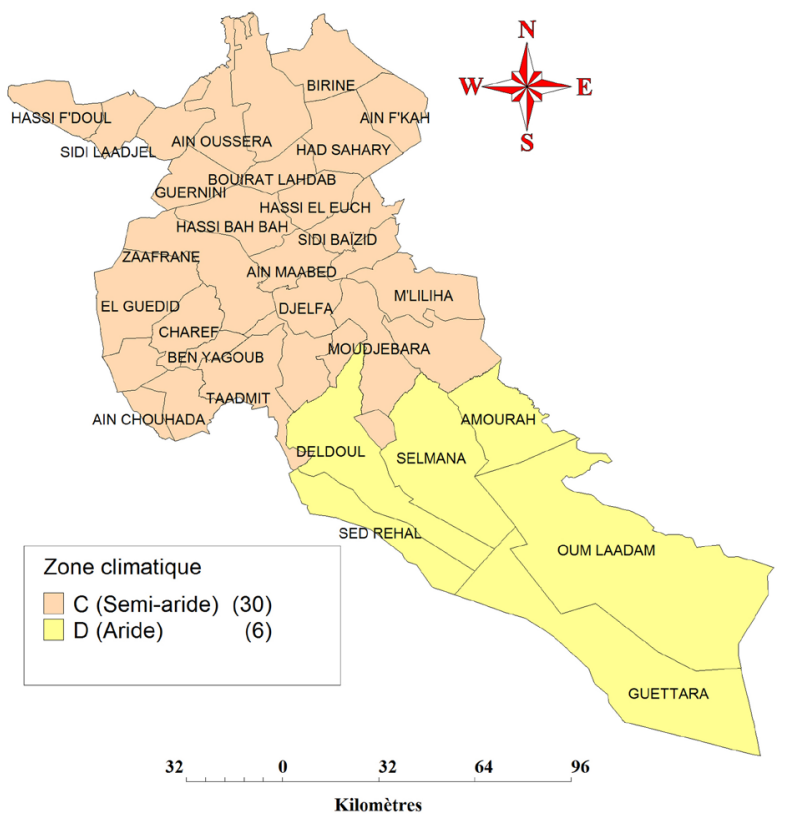

Fig. 1. Climate zone in the department of Djelfa. Based on DTR 3.2: 2004.

municipalities with 30 municipalities situated in a semi-arid climate zone in the north of the prefecture and 6 municipalities in an arid one in the south (Fig. 1).

The climate is hot dry in summer and cold, dry in winter. The $\mathrm{HDD}_{20}$ and $\mathrm{CDD}_{27}$ according to a comfort range of $20-27^{\circ}$ (DTR C3.2 and C3.4: 2004 ) is 2,216 and 265 respectively. The monthly average temperature in winter is around $6.5^{\circ} \mathrm{C}$ with a minimum of $-4^{\circ} \mathrm{C}$. The monthly average temperature in summer is around $28^{\circ} \mathrm{C}$ with a maximum of $42^{\circ}$ (Fig. 2).

Sources: adapted by the author: ${ }^{*},{ }^{* *}$ from De Villaret 1995 and *** from Meteonorm software).

The temperature variation between 1930 and 2004 considers only Djelfa, the chief town of the department. This graph shows a clear increase in temperature with an average of $2.53^{\circ}$. This increase could be explained by global warming.

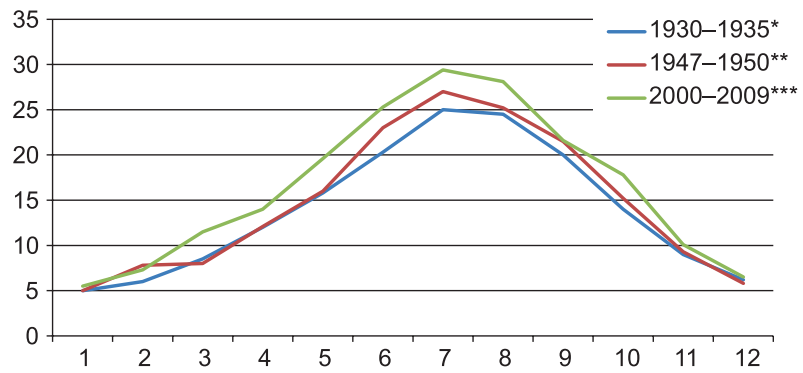

Fig. 2. Temperature variation between 1930 and 2004 . 


\section{Method}

\section{Collection and management of data}

\section{Collecting energy consumption of municipalities}

Energy consumption is acquired from Sonelgaz (2013), the firm in charge to invoice energy consumption in Algeria. The energy data contains the 2013 gas and electricity consumption of residential buildings of Djelfa municipalities. The following figure presents the energy consumption and the density for the year 2013.

\section{Estimation of the energy consumption for 2008}

The housing and household variables are included in the 2008 census data (ONS 2008) and in order to be able to assess their implication in the energy consumption which are available for

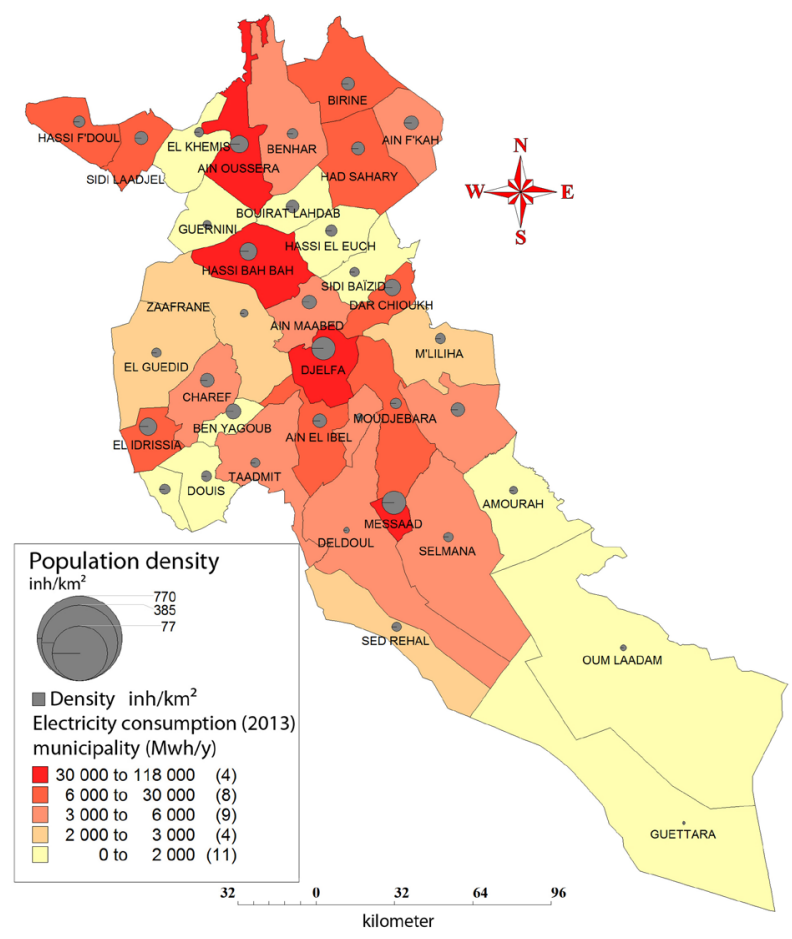

2013, we have performed two estimating models based on multivariate linear regression to be able to compute the energy consumption of both electricity and gas for the year 2008. Gas and electricity costs have not changed from 2008 to 2013 and the climate conditions and occupants' behaviour are considered as stable in this era.

All the data were checked to ensure it is normally distributed before performing multiple linear regression. Variables which do not match conditions of normality within a value larger than 1 for Skewness or out of the range of 2, -2 for Kurtosis test (Kim 2013) were transformed before being used in the analysis. We applied a $\log 10$ transformation to match the normality requirement (Table 1).

For the gas consumption, the model considers the number of subscribers linked to the gas network and the population number. The performed

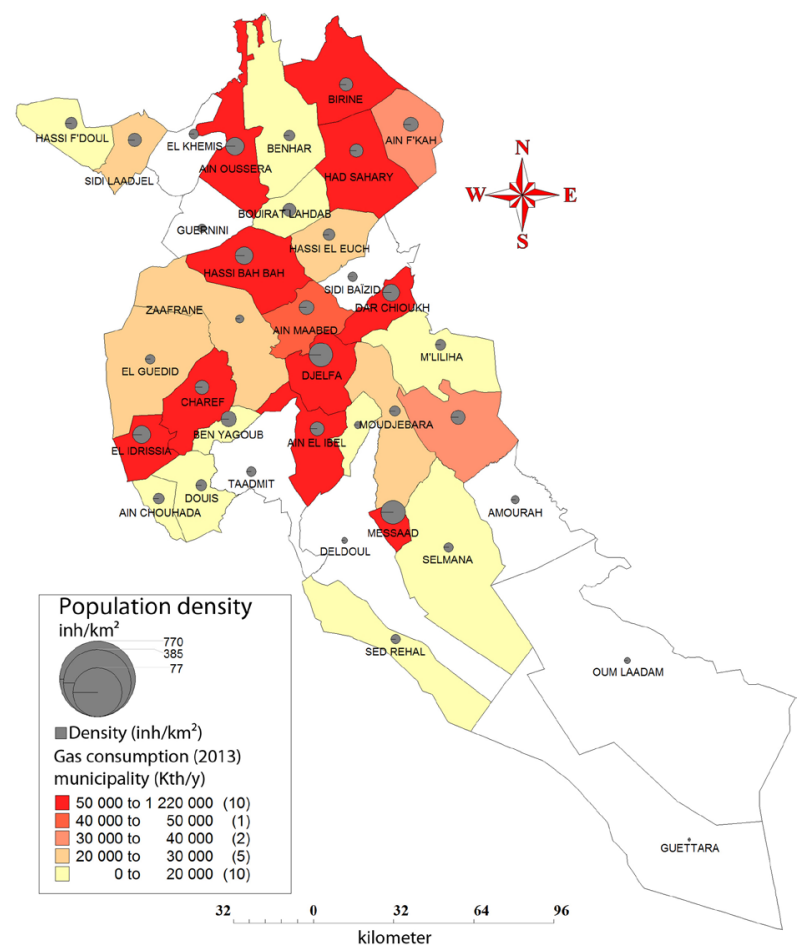

Fig. 3. Consumption of (a) electricity and (b) gas by residential buildings in 2013.

Table 1. Mean values, standard deviation and test of normality of the variables.

\begin{tabular}{|l|r|c|c|c|c|c|}
\hline \multicolumn{1}{|c|}{} & & & & \multicolumn{2}{c|}{ With log10 transformation } \\
\hline Variables (2013) & Mean & Std deviation & Skewness & Kurtosis & Skewness & Kurtosis \\
\hline gas subscribers & 3126.86 & 7523.27 & 4.35 & 21.32 & 0.80 & 0.13 \\
\hline gas consumption (Kth) & 80545.56 & 210208.39 & 4.84 & 25.86 & 0.72 & 0.11 \\
\hline electricity subscribers & 3968.75 & 8209.25 & 4.13 & 19.38 & 0.74 & 0.56 \\
\hline electricity consumption (mwh) & 10139.75 & 21255.03 & 4.18 & 19.66 & 0.51 & 0.56 \\
\hline number of population & 35667.14 & 64194.61 & 4.51 & 22.92 & 0.32 & 1.77 \\
\hline number of housing & 6256.29 & 9888.58 & 4.03 & 18.07 & 0.91 & 0.59 \\
\hline
\end{tabular}



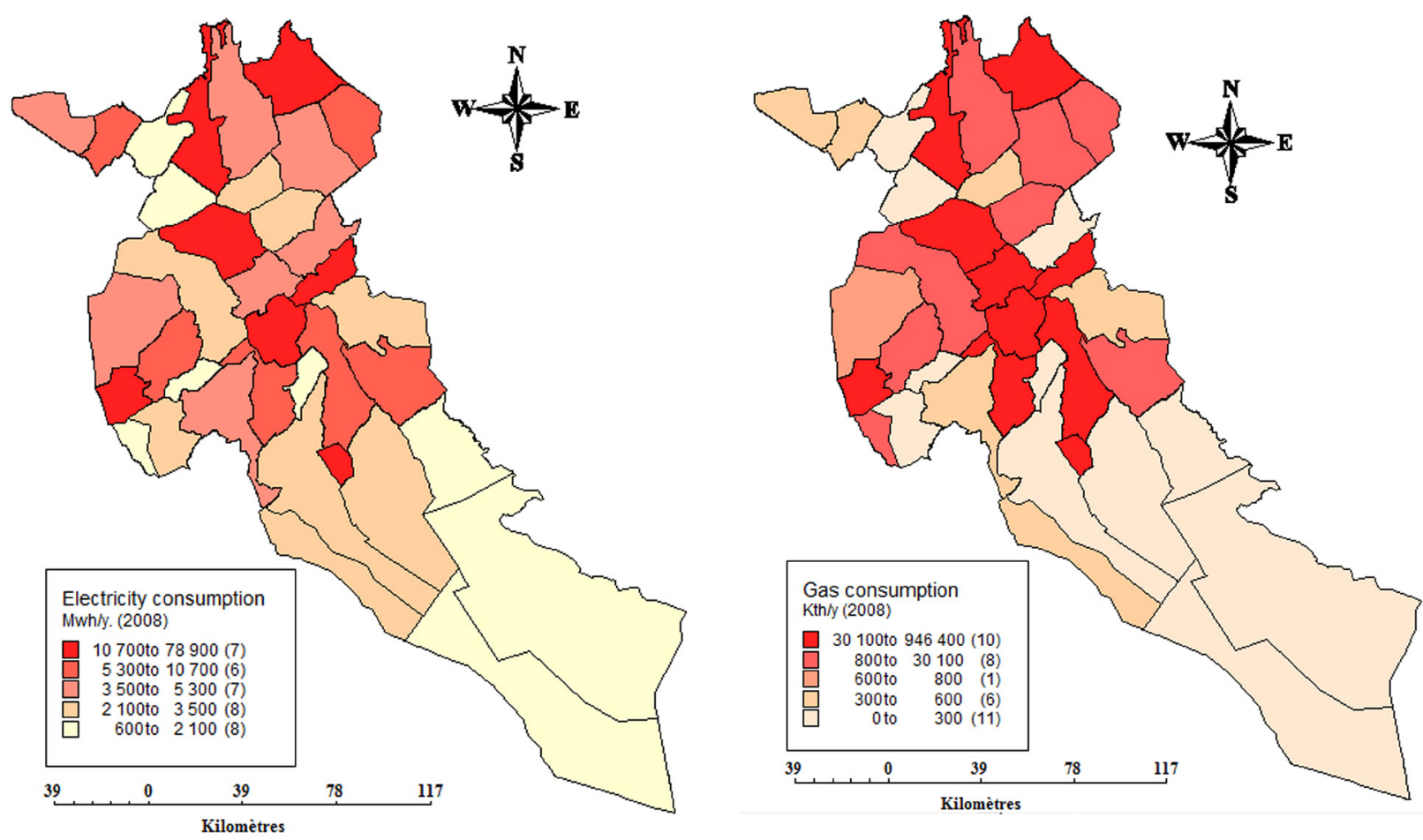

Fig. 4. Gas and electricity consumption in 2008 per municipality.

model presents an accuracy of $98.6 \%$ ( $\mathrm{R}^{2}$ value) for the gas model. The electricity model is also performed with an accuracy of $93.7 \%$. The model considers only the number of electricity consumers and the number of dwellings per municipality (Fig. 4, 5 and Table 2).

To validate the models performed, the normality requirement is also checked for the standardised residual based on the Skewness, Kurtosis, Kolmogorov-Smirnova and ShapiroWilk tests. Moreover, the results presented on Table 3 validate the models performed. The table also presents the values of tests which match the conditions of normality and validate the model.

Based on these two models, we have estimated energy consumption for the year 2008 by

Table 2. Summary of the gas and electricity model.

\begin{tabular}{|c|c|c|c|c|c|c|c|c|c|}
\hline \multicolumn{5}{|c|}{ Electricity model summary $\left(\mathrm{R}^{2}=0.937\right)$} & \multicolumn{5}{|c|}{ Gas model summary $\left(\mathrm{R}^{2}=0.986\right)$} \\
\hline \multirow{2}{*}{ model } & \multicolumn{2}{|c|}{$\begin{array}{l}\text { unstandardised } \\
\text { coefficients }\end{array}$} & \multirow{2}{*}{$\begin{array}{c}\begin{array}{c}\text { standardised } \\
\text { coefficients }\end{array} \\
\text { Beta }\end{array}$} & \multirow{2}{*}{ Sig. } & \multirow{2}{*}{ model } & \multicolumn{2}{|c|}{$\begin{array}{l}\text { unstandardised } \\
\text { coefficients }\end{array}$} & \multirow{2}{*}{$\begin{array}{c}\text { standardised } \\
\text { coefficients } \\
\text { Beta }\end{array}$} & \multirow{2}{*}{ Sig. } \\
\hline & B & $\begin{array}{l}\text { Std. } \\
\text { error }\end{array}$ & & & & B & $\begin{array}{l}\text { Std. } \\
\text { error }\end{array}$ & & \\
\hline (constant) & 0.927 & 0.268 & & 0.002 & (constant) & 1.635 & .163 & & .000 \\
\hline $\begin{array}{c}\log 10 \_ \text {electricity } \\
\text { subscribers }\end{array}$ & 1.239 & 0.097 & 1.178 & 0.000 & $\begin{array}{l}\text { log10_gas_ } \\
\text { subscribers }\end{array}$ & 1.141 & .050 & 1.097 & .000 \\
\hline $\begin{array}{l}\text { log10_number_ } \\
\text { of housings }\end{array}$ & -0.372 & 0.145 & -0.238 & 0.015 & $\begin{array}{l}\text { log10_popula- } \\
\text { tion number }\end{array}$ & -.161 & .065 & -.120 & .020 \\
\hline
\end{tabular}

Table 3. Normality tests of the models.

\begin{tabular}{|c|c|c|c|c|c|c|c|}
\hline \multicolumn{9}{|c|}{ Validation test } \\
\hline Skewness & Kurtosis & $\begin{array}{c}\text { Kolmogorov-Smirnova } \\
(\text { KS })\end{array}$ & $\begin{array}{c}\text { Shapiro- } \\
\text { Wilk }\end{array}$ & Skewness & Kurtosis & Kolmogorov-Smirnova & $\begin{array}{c}\text { Shapiro- } \\
\text { Wilk }\end{array}$ \\
\hline .745 & .426 & $.200^{*}$ & $.092^{*}$ & -.334 & -.718 & $.200^{*}$ & $.570^{*}$ \\
\hline
\end{tabular}

* Both tests, Kolmogorov-Smirnova and Shapiro-Wilk have a $p$-value greater than 0.05 which indicates normal distribution (Ghasemi, Zahediasl 2012; Öztuna et al. 2006). 

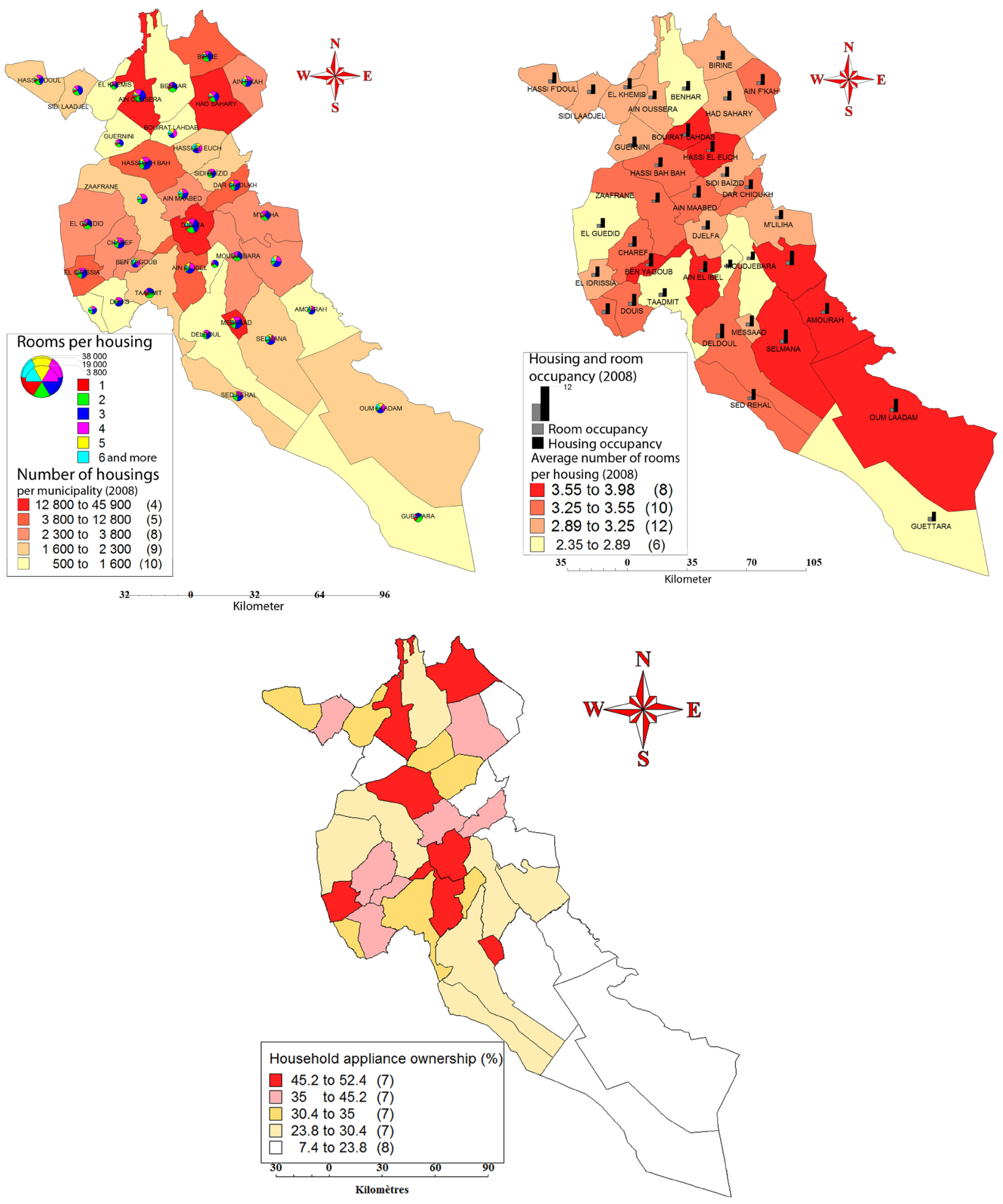

Fig. 5. (a) housing number and size, (b) household size, room occupancy and average number of rooms per housing, (c) appliance ownership (TV, cooker, washing machine, refrigerator and air conditioner). 
introducing the number of subscribers of gas and electricity and the number of dwellings and population per municipality for 2008. The maps in Fig. 4 present the household gas and electricity consumption of 2008 in the department of Djelfa.

\section{Managing the 2008 census data}

In Algeria, "The General Census of Population and Housing" is carried out by the government every ten years to collect information about the population and housing. It contains mainly information about dwellings, households and population characteristics. For our research, we selected and organised the census as follows:

1. the population distribution which contains its density, its number in the centre of municipalities, the number of population living in a secondary agglomeration and a scattered zone;

2. household characteristics, average age per municipality and the education level and Household with Responsible Person (HRP) over the age of 60 ;

3. housing occupancy with the household size, room occupancy and mean area per dwelling;

4. housing types, with collective housing, individual and traditional housing;

5. the household appliance, which contains appliance ownership; it represents the ownership of TV, cooker, refrigerator, washing machine and air conditioner;

6. energy consumption organised as gas and electricity consumption per municipality and housing;

7. the climate zone which contains two zones, an arid and a semi-arid one.

\section{Results and discussion}

\section{Analysis strategy}

Statistical analysis of the variables chosen was performed using the SPSS software. And as presented above, the normality test was checked for all the parameters before performing analysis. A $\log 10$ variables transformation was performed to each parameter that does not match the normality test. Only the density and the rate of households with a responsible (HRP) person over the age of 60 per municipality did not match the normality test.

\section{Data analysis}

\section{Principal components analysis as correlation diagnosis}

Frequently in experimentation, we don't know the logic of the correlation between variables that we study. PCA gives the ability to reduce the dimension of a large data set which permits revealing the potential correlations and extracts the most significant variations between variables (Owen 2014). PCA proceeds by transforming the original data set into a meaningful basis in such a way that the transformed data retains most of the variations exhibited in the original data (Owen 2014). PCA is a kind of algorithm in biometrics, which is based on the pattern recognition of the data once transformed and projected into the space. If the distance between variables is small enough the correlation could then be identified (Karamizadeh 2013). The distance between variables projected into the space reveals profile clustering. In our case, based on the municipalities' data presented above, PCA reveals 4 profiles of municipalities according to their household gas and electricity consumption as presented in Fig. 6: (1) municipalities which consume more energy at the housing and municipality scales; they represent the worst profile, (2) municipalities which consume less energy at both scales, (3) municipalities consuming less energy at the municipality scale and more consumption at the housing scale, and (4) profile of municipalities consuming more energy at the municipality scale and less at the housing scale.

The performed PCA (Fig. 6) shows a bi-axial projection, the $\mathrm{X}$ axis separates municipalities according to the energy consumption at the housing scale. The municipalities projected under the $X$ axis consume more energy than those projected above. Whereas the $\mathrm{Y}$ axis distinguishes the municipalities according to the energy consumption considered at the municipality scale which means that all the municipalities projected on the $Y$ axis' right side consume more energy than municipalities projected at the $Y$ axis' left side.

Table 4 summarises the clusters according to the population distribution, housing characteristics, housing occupancy, typology, and appliance ownership. The clusters identified based on PCA presented below are: (1) cluster 1 representing $8.3 \%$, shown in red, contains all municipalities which consume more energy at both scales; (2) 


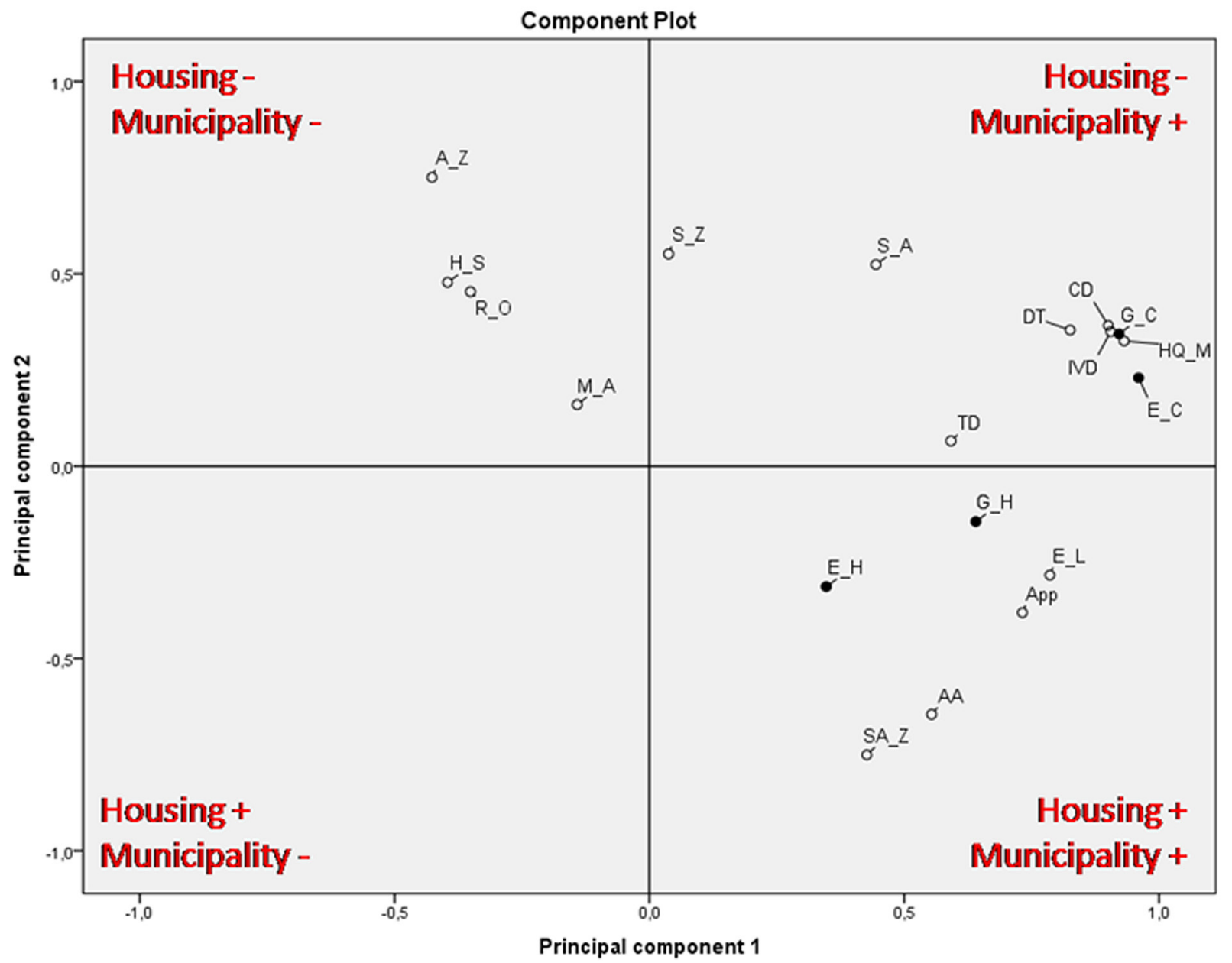

Fig. 6. PCA of all the variables used to cluster municipalities according to their population characteristics, dwelling typology, population distribution, climate zone, and appliance ownership.

Legend: $A \_Z=$ arid zone, SA_Z= semi-arid zone H_S = household size, R_O = room occupancy, M_A = mean area, HQ_M = population number living in headquarter municipality, S_Z = population number living in scattered zone,

S_A = population living in secondary agglomeration, DT = density, CD = collective dwelling, IVD = individual dwelling, TD = traditional dwelling, G_C = gas consumption per municipality, E_C = electricity consumption per municipality, G_H = gas consumption per housing, E_H = electricity consumption per housing, E_L = education level, App = appliance ownership, AA = average age per housing per municipality.

cluster 2 representing $72.72 \%$, shown in orange, consumes more energy at the housing scale and less at the municipality scale; (3) cluster 3 representing $2.8 \%$ consumes less energy at the housing scale and more energy at the municipality scale. The energy consumed at the municipality scale for clusters 1 and 3 is explained by the high number of population whereas clusters 2 and 4 are thinly populated and less dense. (4) Cluster 4 representing $(16.7 \%)$ shown in green, contains less energy at housing and municipality scales. This cluster has the lowest density and it is located in an arid climate zone. This cluster is characterised by the lowest rate of household appliances, and has a young population with a minimum education level.
According to the results of this PCA, socio-economic criteria have a contrasting impact on household electricity and gas consumption. Based on Pearson's bivariate correlation and an analysis of the structural equation model (SEM), the next section discusses with more accuracy the impact of the density, average age, education level, mean area per dwelling, household size and appliance ownership on energy consumption.

Based on these tables, the most important factors reducing the gas and electricity consumption at the housing scale are: an increase in the household size, a room occupancy rate, density and the population living in the municipality centre and 


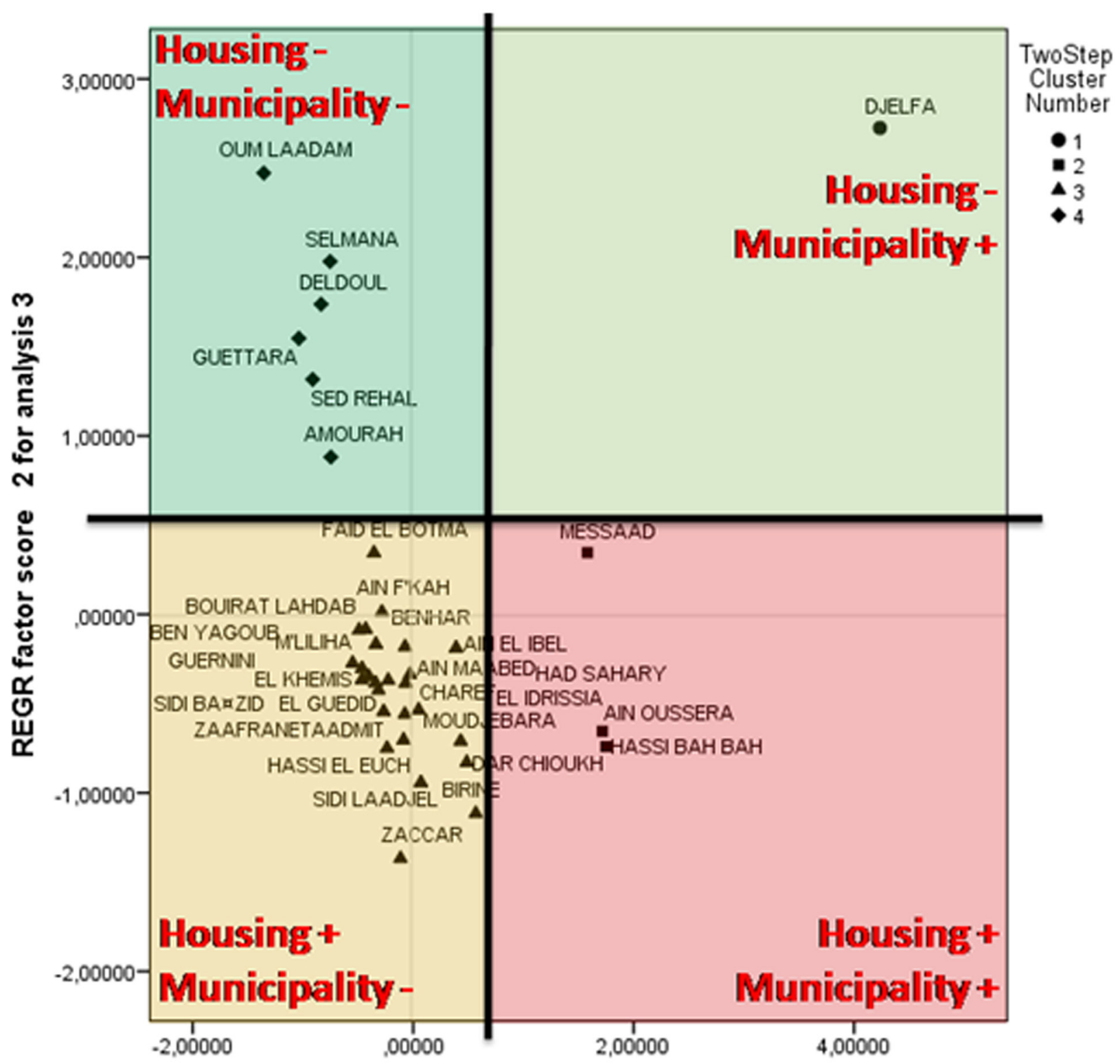

\section{REGR factor score 1 for analysis 3}

Fig. 7. Projection of municipalities according to PCA.

secondary agglomeration as well as a decrease in the housing area and dwelling types.

The factors generating more energy consumption are: an increase in the education level, an average age and appliance ownership.

All the municipalities situated in the semi-arid climate zone consume more energy that those situated in the arid zone. This observation could be explained by the population number which is higher in the semi-arid zone than in the arid zone. However, less energy consumed at the housing scale is observed in the Djelfa municipality, the chief town of the department. This municipality is the densest, and it has the youngest population with a moderate education level, mean area per housing, and the housing and room occupancy lower than in the arid zone.

The next section evaluates with Pearson's bivariate analysis the influence of household and housing variables, density and household appliance ownership.

\section{Pearson's bivariate correlation analysis}

The correlation analysis evaluates the degree of association between two continuous variables. $\mathrm{R}$ is Pearson's correlation coefficient. It measures the linear dependence between the two variables. Meanwhile $\mathrm{R}^{2}$ expresses the shared variance 
calculated by squaring the coefficient of correlation $R$. The value of $R^{2}$ could have a value from 0 to 1 where 1 indicates a perfect fit and 0 indicates no correlation. The $P$ value is the measure of the probability. A correlation is considered as significant for a $P$ value less than 0.05 or 0.01 level (Chen et al. 2013; Field 2009). The results of the correlation are shown on Table 5.

Table 4. Characteristics of clusters.

\begin{tabular}{|c|c|c|c|c|c|c|}
\hline \multicolumn{3}{|l|}{ Cluster } & 1 & 2 & 3 & 4 \\
\hline \multicolumn{3}{|l|}{ Label } & 口 & $\Delta$ & $\bullet$ & 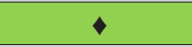 \\
\hline \multicolumn{3}{|c|}{ Housing energy consumption } & + & + & - & - \\
\hline \multicolumn{3}{|c|}{ Municipality energy consumption } & + & - & + & - \\
\hline \multicolumn{3}{|l|}{ Size } & $3(8.3 \%)$ & $26(72.2 \%)$ & $1(2.8 \%)$ & $6(16.7 \%)$ \\
\hline \multirow[t]{14}{*}{ Variables } & \multicolumn{2}{|c|}{ climate zone } & semi-arid & semi-arid & semi-arid & arid \\
\hline & \multirow[t]{4}{*}{$\begin{array}{l}\text { population distri- } \\
\text { bution }\end{array}$} & density & $\begin{array}{l}\text { average den- } \\
\text { sity }\end{array}$ & low density & dense & low density \\
\hline & & $\begin{array}{c}\text { municipality } \\
\text { centre }\end{array}$ & $\begin{array}{c}\text { moderately } \\
\text { populated }\end{array}$ & $\begin{array}{l}\text { thinly popu- } \\
\text { lated }\end{array}$ & $\begin{array}{l}\text { highly popu- } \\
\text { lated }\end{array}$ & $\begin{array}{l}\text { thinly popu- } \\
\text { lated }\end{array}$ \\
\hline & & $\begin{array}{l}\text { secondary ag- } \\
\text { glomeration }\end{array}$ & $\begin{array}{c}\text { moderately } \\
\text { populated }\end{array}$ & $\begin{array}{l}\text { thinly popu- } \\
\text { lated }\end{array}$ & $\begin{array}{l}\text { thinly popu- } \\
\text { lated }\end{array}$ & $\begin{array}{c}\text { thinly popu- } \\
\text { lated }\end{array}$ \\
\hline & & scattered zone & $\begin{array}{c}\text { moderately } \\
\text { populated }\end{array}$ & $\begin{array}{c}\text { moderately } \\
\text { populated }\end{array}$ & $\begin{array}{c}\text { moderately } \\
\text { populated }\end{array}$ & $\begin{array}{c}\text { highly popu- } \\
\text { lated }\end{array}$ \\
\hline & \multirow{2}{*}{$\begin{array}{c}\text { population charac- } \\
\text { teristics }\end{array}$} & average age & highest rate & moderate rate & lowest rate & lowest rate \\
\hline & & education level & highest rate & low rate & moderate rate & low rate \\
\hline & \multirow{3}{*}{$\begin{array}{l}\text { dwelling occu- } \\
\text { pancy }\end{array}$} & mean area & moderate & high & moderate & less \\
\hline & & room occupancy & moderate & moderate & highest rate & lowest rate \\
\hline & & household size & low rate & moderate rate & lowest rate & highest rate \\
\hline & \multirow[t]{3}{*}{ dwelling typology } & $\begin{array}{l}\text { collective dwell- } \\
\text { ing }\end{array}$ & high rate & low rate & highest rate & lowest rate \\
\hline & & $\begin{array}{l}\text { individual } \\
\text { dwelling }\end{array}$ & high rate & low rate & highest rate & low rate \\
\hline & & $\begin{array}{l}\text { traditional } \\
\text { dwelling }\end{array}$ & high rate & moderate rate & high rate & moderate \\
\hline & \multicolumn{2}{|c|}{ appliance ownership } & highest rate & moderate rate & moderate rate & lowest rate \\
\hline
\end{tabular}

Table 5. Bivariate correlations between energy consumption and households, housing variables, density and appliance ownership.

\begin{tabular}{|c|c|c|c|c|c|c|c|c|c|c|c|c|c|c|}
\hline & A-A & EL & Log10HRP>60 & M_A & H-S & $\mathrm{R}-\mathrm{O}$ & Log10Dt & $\begin{array}{c}\log 10 \\
(\mathrm{~A}-\mathrm{C})\end{array}$ & $\mathrm{C}$ & TV & Refr & WM & App \\
\hline \multirow[t]{2}{*}{ EUI } & $\begin{array}{l}\text { Corre- } \\
\text { lation }\end{array}$ & $.594^{* *}$ & $.521^{* *}$ & $.514^{* *}$ & $-.593^{* *}$ & $-.781^{* *}$ & -.321 & $.335^{*}$ & .280 & $.348^{*}$ & $.490^{* *}$ & $.358^{*}$ & .253 & $.431^{* *}$ \\
\hline & Sig. & .000 & .001 & .001 & .000 & .000 & .057 & .046 & .099 & .038 & .002 & .032 & .137 & .009 \\
\hline \multirow[t]{2}{*}{ G } & $\begin{array}{l}\text { Corre- } \\
\text { lation }\end{array}$ & $.590^{* *}$ & $.551^{* *}$ & $.564^{* *}$ & $-.543^{* *}$ & $-.747^{\text {t* }}$ & $-.330^{*}$ & $.395^{*}$ & .287 & $.390^{*}$ & - & - & - & - \\
\hline & Sig. & .000 & .000 & .000 & .001 & .000 & .049 & .017 & .089 & .019 & - & - & - & - \\
\hline \multirow[t]{2}{*}{$E$} & $\begin{array}{l}\text { Corre- } \\
\text { lation }\end{array}$ & $.362^{*}$ & .018 & -.166 & $-.782^{* *}$ & $-.746^{* *}$ & -.089 & $-.356^{*}$ & .086 & - & .078 & .044 & -.234 & .006 \\
\hline & Sig. & .030 & .916 & .332 & .000 & .000 & .604 & .033 & .616 & - & .653 & .800 & .170 & .973 \\
\hline
\end{tabular}

* - Correlation is significant at the 0.05 level (2-tailed).

** - Correlation is significant at the 0.01 level (2-tailed).

With, EUI: energy use index per capita $\left(\mathrm{kwh} / \mathrm{m}^{2} . \mathrm{y}\right)$, G: household gas consumption per capita $\left(\mathrm{kwh} / \mathrm{m}^{2} . \mathrm{y}\right)$, E: household electricity consumption per capita $\left(\mathrm{kwh} / \mathrm{m}^{2} . \mathrm{y}\right)$, AA: average age, El: education level, $\log 10 \mathrm{HRP}>60$ : $\log 10$ household with responsible person older than 60, M_A: mean area $\left(\mathrm{m}^{2}\right)$, HS: household size, RO: room occupancy, Log10Dt: $\log 10$ density, Log10(A-C): $\log 10$ air conditioner, C: cooker ownership, TV: TV ownership, Refr.: refrigerator ownership, WM: washing machine ownership, App: mean appliance ownership. 
Correlations between energy and household variables

The average age is positively correlated with the energy consumption in the department of Djelfa, while the HRP $>60$ indicates a negative correlation with the electricity consumption and a positive one with the gas consumption. The average age as considered in our analysis does not show a high difference between municipalities because the entire department of Djelfa has a young population in comparison with the north department of Algeria. The mean age for the whole department is about 30 . This is why we have introduced the $\mathrm{HRP}>60$ rate as a distinctive criterion to assess the influence of the age on the energy consumption. The older households consume more gas and less electricity. According to Yohanis et al. (2008), household responsible person (HRP) dictates the household behaviour which consequently influences the energy consumption. Rory et al. (2015) added that households with a HRP over 65 years old consume less electricity than the rest of the population. In Ireland, Leahy and Lyons (2010) confirm this tendency, HRPs between 45 and 64 years of age consume more electricity and for those over 65 electricity consumption decreased significantly. Similarly, Kavousian et al. (2013) recorded almost the same findings, households with HRPs over 55 years old consume less electricity. The significant effect of HRP age on electricity consumption was also acknowledged by Bedir et al. (2013), Brounenetal (2012). Also, a lower electricity consumption could be accounted for by the income of older households which could have lower incomes than working households (Rory 2015).

The main energy used for heating in Algeria as well as in Djelfa is gas energy. Fanger (1972, reported by Chen et al. 2013) found that the difference between persons from 20 to 65 years old in terms of thermal comfort perception is about $4.7 \mathrm{w} / \mathrm{m}^{2}$. According to Liao and Chang (2002), Linden et al (2006) and Chen et al. (2013), older persons tend to consume more energy for heating

Table 6. Model Fit Indices of per-capita gas consumption.

\begin{tabular}{|c|c|c|c|c|c|c|}
\hline & $d f$ & $x^{2}$ & $\begin{array}{c}\text { Probabil- } \\
\text { ity level }\end{array}$ & RMSEA & NFI & CFI \\
\hline gas model & 8 & 8.908 & 0.35 & 0.057 & 0.964 & 0.996 \\
\hline
\end{tabular}

than younger ones. For the case of Hangzhou, in China (Chen et al: 2013), it has been found that age is more important than income.

The education level in the department of Djelfa does not affect electricity consumption, as shown in several studies like Bedir et al. (2013) for the Dutch case and Cramer et al. (1985) for the US, who confirm these findings. In Denmark, on the contrary, Gram-Hanssen et al. (2004) found that with a higher level of education the electricity consumption decreases. Besides, Zhou and Teng (2013) show that in China the electricity consumption increases with the education level.

On the other hand, gas consumption increases with the education level in the department of Djelfa. In Sudan, Hammad et al. (2014) found a positive correlation between gas consumption and the education level of a household. Whereas in Ireland, Harold et al. (2015) found that with a higher education level gas consumption decreases because of the greater awareness regarding environmental risks.

The education level has to be linked to environmental awareness as it has been done in China where two groups of $124\left(62^{\star} 2\right)$ households were investigated. The first group has received environmental and best practice oriented training and the second group has not got any training. The measurement of the energy used during July 2008 showed a difference of $10 \%$ between the two groups (Ouyang, Hokao 2009).

\section{Correlations between energy and housing variables}

The floor area per dwelling in the department of Djelfa has a negative impact on both electricity and gas energy consumption. Our results coincide with Brounen et al. (2012) who found a negative correlation between the number of rooms and electricity consumption. This can be explained by the ineffective use of the total floor area. Apart from that, a lot of studies showed a positive correlation between electricity and the floor area which confirms the intuitive consideration (Baker, Rylatt 2008; Tso, Yau 2007; Wiesmannet al. 2011; Kavousian et al. 2013). And in other studies, no impact of the floor area on the electricity consumption has been found (Bedir et al. 2013; Tso, Yau 2007).

Kelly (2011) examined the impact of several factors influencing the energy consumption in 
the UK and the household size seems to have the largest impact on energy consumption, followed by the floor area and the income. In the case of the department of Djelfa, the household size shows a negative correlation for both electricity and gas energy consumption. This can be explained by the income. In the department of Djelfa, the highest household size is observed in the municipalities of the arid zone characterised by the lowest rate of appliance ownership, the lowest linking rate to gas network and the inhabitants' lowest education level.

The room occupancy rate in the department of Djelfa has a negative impact on gas consumption because in Algeria and also in Djelfa, we basically find one heater located in the hall of housing that cannot be controlled from the rooms. Also, higher room occupancy rate is observed with moderate and low household income. Whereas, the occupancy of rooms seems not to have a significant impact on electricity consumption in the department of Djelfa. Alam et al. (1998) and Ouedraogo (2006) have obtained the same results that the room occupancy reduces the energy consumption.

\section{Correlations between energy and density variables}

The conclusion pointing to the density as an important factor reducing energy consumption is contrasting and still controversial in the scientific literature (Yekang 2013). Studies showed a negative correlation (Salat 2011; Holden, Norland 2005; Boukarta, Berezowska 2017). Steadman (1979), Hui (2001) and Larivière et al. (2009) showed a contrary logic, stating that in higher density the energy demand due to the mobility reduces, while it increases for buildings. In the department of Djelfa, density seems also to have a positive significant impact on per-capita gas consumption and a negative impact on per-capita electricity consumption. In the densest zone, a decrease of solar radiation could increase the heating demand and could also decrease the cooling demand which explains the positive correlation with gas consumption and negative one with electricity consumption as well. Inter alia, VandeWeghe and Kennedy (2007) showed that in Finland, the densest areas match the smallest living spaces, which could, relatively, link the density to the floor area findings.
The household appliance ownership has also contrasting impact. Intuitively, the highest rate of appliance ownership has to increase the energy consumption. Nielsen (1993) showed in Denmark, that an increase of $1 \%$ in appliance ownership induces a rise of $1 \%$ in the electricity consumption. On the other hand, and based on 12 types of appliances, Carlson et al. (2013) explained about $80 \%$ of the electricity consumption in US households, and with 5 types of appliances, the authors explained about $50 \%$ of the household electricity consumption. And Bedir et al. (2013) showed a variation of $21 \%$ of the Netherland household electricity consumption based on the number of appliances.

The ownership of an air conditioner in the department of Djelfa has no significant correlation with the household electricity consumption. This could be explained, firstly, by the low ownership rate of the air conditioner with a maximum rate about $40 \%$ in the headquarter (municipality of Djelfa). In other words, this lack of significance could be ascribed to the income criteria. The same conclusion has been reported by Kavousian et al. (2013) and Bedir et al. (2013) who confirm that there is no effect of the ownership of the air conditioner in California, USA, and in the Netherlands respectively. Besides, several studies showed a positive correlation between the ownership of an air conditioner and the electricity consumption in the south-east of Canada (Ndiaye, Gabriel 2011), south-west of China (Zhou, Teng 2013) and Hong-Kong (Tso, Yau 2007) who have found that the ownership of an air-conditioner explains about $59 \%$ of the electricity consumption. The significant relationship is observed in regions with hot summers (Jones et al. 2015).

Cooker ownership has a significant positive correlation $(+39 \%)$ with the gas consumption in the department of Djelfa. In the developed countries, the cooking appliance is based on electricity consumption and it has a positive impact on it (McLaughlin et al. 2012; Parti 1980; Halvorsen, Larsen 2001). On the other hand, Carter et al. (2011) found that the impact of cooker ownership has a negative correlation with energy consumption.

In the department of Djelfa, television ownership has no significant impact on electricity consumption and our results match those of Leahy 
and Lyons (2010) who have found that television ownership affects the household electricity consumption to a lower degree. But other studies (McLaughlin et al. 2012; Kavousian et al. 2013) have found its positive impact on household electricity consumption.

Refrigerator ownership has no significant impact on the household electricity consumption in Djelfa which is in accordance with the results of Leahy and Lyons (2010) and Carter et al. (2011). On the other hand, other studies showed a positive correlation of refrigerator ownership (Kavousian et al. 2013; Parti 1980).

Washing machine ownership does not seem to have significant impact on the electricity consumption as well as found by Tso and Yau (2007), Leahy and Lyons (2010). This means that its use is not important in the department of Djelfa. However, in other studies, a positive impact of the washing machine has been found (Carter et al. 2011; Halvorsen, Larsen 2001).

The results presented above are in accordance with our expectations and it can be stated that the household, housing and density are more important contributors to gas and electricity consumption than appliance ownership. However, Pearson's correlation analysis is not sufficient either to identify the causal relationship between parameters and/ or to estimate the impact of each parameter. To be able to identify the impact of every parameter a path analysis was carried out based on a SEM analysis to determine the effect of the selected parameters from the census data on energy consumption.

\section{Path analysis}

To estimate the contribution of each factor we used Structural Equation Modeling (SEM) which is a statistical technique used to identify the potential combination between variables and to explain the observed phenomenon. SEM uses a path graphical approach to represent a set of hypothesis which could explain the relationship between factors of the phenomenon observed, and it is based on factor analysis and regression techniques. To validate SEM, a set of the following indices is required: (1) Root Mean Square Error of Approximation (RMSE) has to be smaller than 0.06 to 0.08 with a confidence interval (Schreiber et al. 2006; Hooper et al. 2008), (2) Normal Fit Index (NFI) has to be greater than

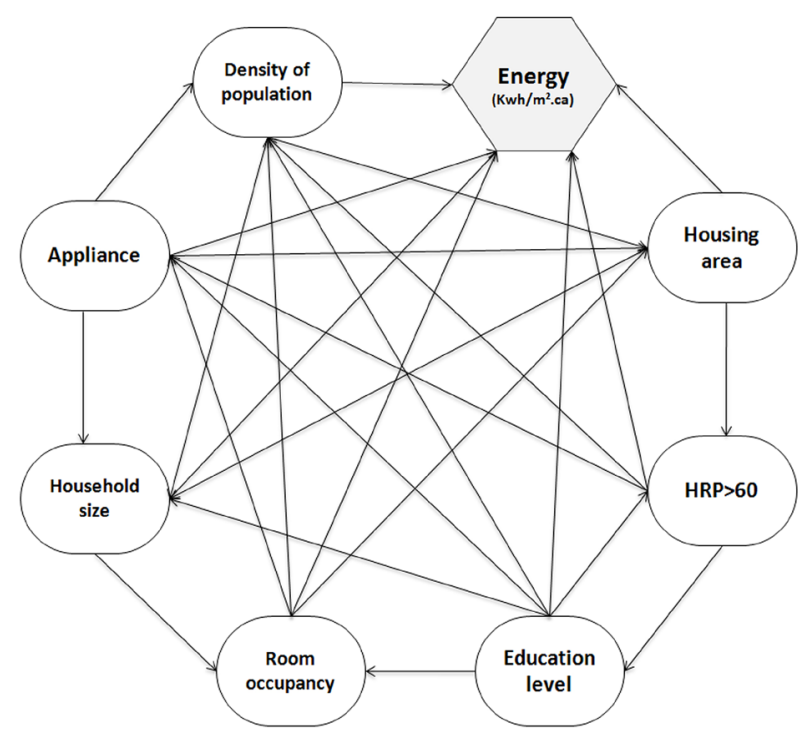

Fig. 8. Path analysis containing all possible hypotheses.

0.95 (Hu, Bentler 1999), and (3) Comparative Fit Index (CFI) has to be close to or higher than 0.95 (Schreiber et al 2006; Iacobucci 2010) or bigger than 0.80 (Hooper et al. 2008). Once the model fits indices, it is considered a good one and we can estimate the total, direct and indirect effect of each factor.

In our case, we took into account all the parameters presented above and considered the bivariate correlation to estimate the contribution of each parameter to a structural logic. Based on the literature, we considered the entire possible hypothesis in the path presented below.

By testing the hypothesis presented above, we obtained two structural models explaining the household gas and electricity consumption in the arid and semi-arid climate zone of the department of Djelfa.

Estimating elasticity of gas consumption in the department of Djelfa Fit indices

As presented in the table below, all the indices fit the limits explained above which suggests that the model obtained is acceptable.

The figure below shows only the significant paths with the significance level of 0.07 and 0.05 , and less than 0.01 (Table 7). The non-significant paths are hidden for clarity considerations. The path presented below shows the standardised direct effect of each factor on per-capita household gas consumption. 


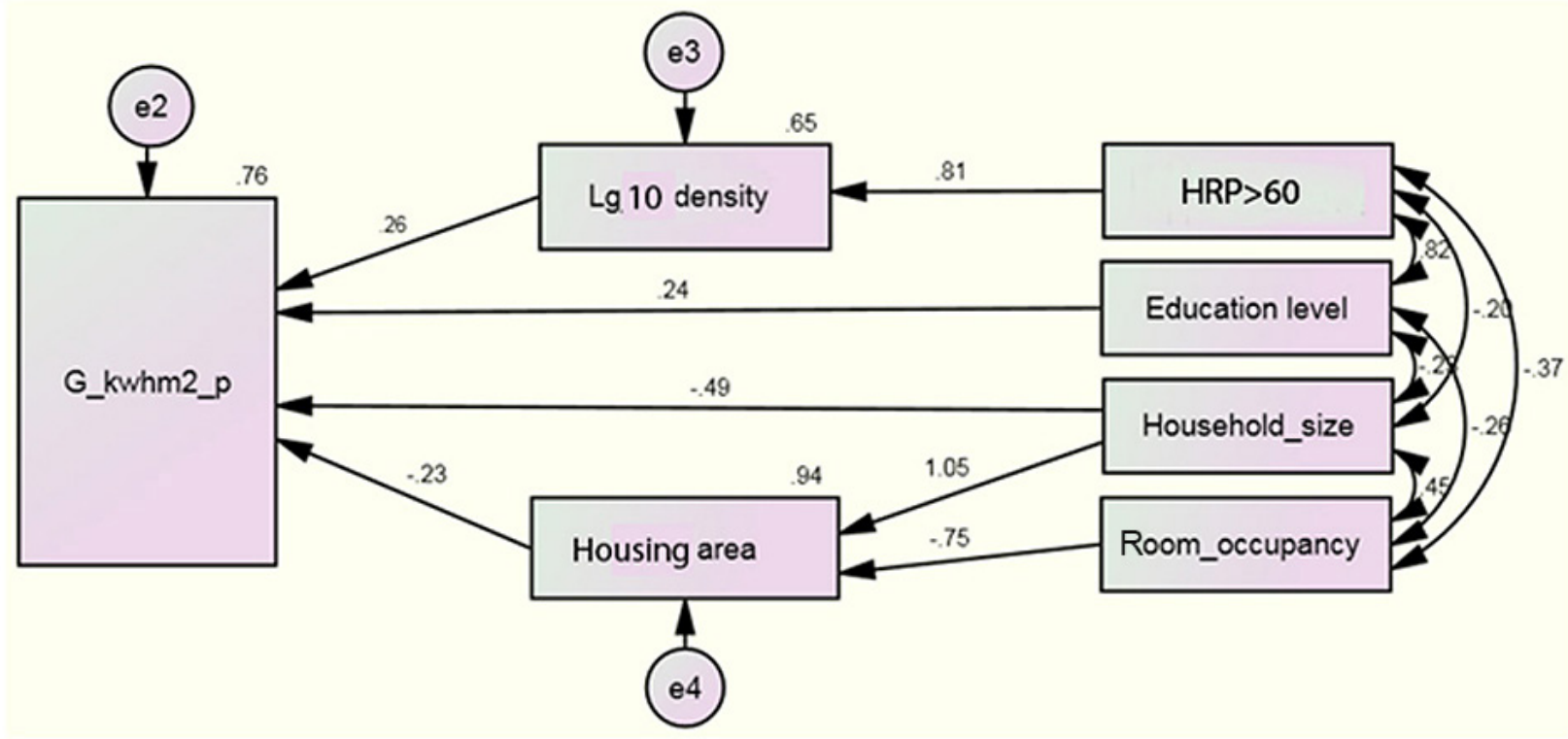

Fig. 9. Standardised direct effect for gas consumption per kwh/person. $\mathrm{m}^{2} . \mathrm{y}$.

Table 7. Path analysis: standardised direct effect.

\begin{tabular}{|l|c|c|c|c|c|}
\hline & & & Estimate & Standard Err & $P$ \\
\hline housing area & $\leftarrow$ & households size & 1.047 & & $* *$ \\
\hline housing area & $\leftarrow$ & room occupancy & -.745 & & $* * *$ \\
\hline log 10 density & $\leftarrow$ & HRP>60 & .805 & & $.021^{* *}$ \\
\hline gas_kwhm2_p & $\leftarrow$ & $\log 10$ density & .257 & & $.032^{* *}$ \\
\hline gas_kwhm2_p & $\leftarrow$ & education level & .239 & & $.052^{*}$ \\
\hline gas_kwhm2_p & $\leftarrow$ & housing area & -.234 & & $* * *$ \\
\hline gas_kwhm2_p & $\leftarrow$ & households size & -.493 & & \\
\hline
\end{tabular}

***significant at 0.001 level

**significant at 0.05 level

*significant at 0.06 level

\section{Age effect}

The SEM analysis shows that households with a responsible person over the age of 60 have a positive indirect contribution. A standardised unit of household age more than 60 will increase per-capita household gas consumption indirectly through the density impact by $0.207\left(0.805^{*} 0.257\right)$. The results also demonstrate that household age is not linked to a housing area and they reveal as well that older household in the department of Djelfa are mainly concentrated in the densest zone of the department (0.805).

\section{Room occupancy effect}

The number of persons per room has no direct impact on household per-capita gas consumption while the indirect effect is positive through the housing area with a value of $0.174\left(-0.745^{*}-\right.$ $0.264)$. Not surprisingly, the housing area affects directly and negatively the room occupancy $(-0.745)$.

Table 8. Direct, indirect and total effect of household, housing and density variables on per-capita gas consumption.

\begin{tabular}{|l|c|c|c|c|c|c|c|c|c|c|c|c|c|c|c|c|c|c|}
\hline & \multicolumn{4}{|c|}{ HRP>60 } & \multicolumn{4}{c|}{ Room Occupancy } & \multicolumn{3}{c|}{ Households size } & \multicolumn{3}{c|}{ Education } & \multicolumn{3}{c|}{ Level } & \multicolumn{2}{c|}{ Housing area } & \multicolumn{2}{c|}{ Log 10 Density } \\
\hline effect & Dir & Ind & tot & Dir & Ind & tot & Dir & Ind & tot & Dir & Ind & tot & Dir & Ind & tot & Dir & Ind & tot \\
\hline M_A & .000 & .000 & .000 & -.745 & .000 & -.745 & 1.047 & .000 & 1.047 & .000 & .000 & .000 & .000 & .000 & .000 & .000 & .000 & .000 \\
\hline density & .805 & .000 & .805 & .000 & .000 & .000 & .000 & .000 & .000 & .000 & .000 & .000 & .000 & .000 & .000 & .000 & .000 & .000 \\
\hline gas* $^{*}$ & .000 & .207 & .207 & .000 & .174 & .174 & -.493 & -.245 & -.738 & .239 & .000 & .239 & -.234 & .000 & -.234 & .257 & .000 & .257 \\
\hline
\end{tabular}

*Gas: per-capita gas consumption (kwh/m².y.capita). 


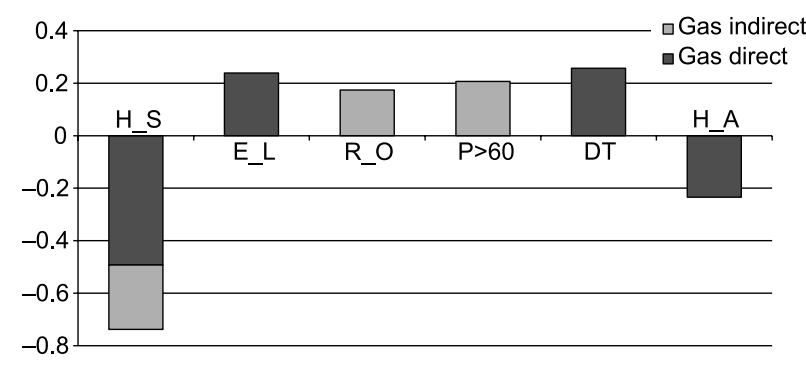

Fig. 10. Direct and indirect effect of variables on household gas consumption. With: H_S: household size, E_L: education level, R_O: room occupancy, HRP>60: household with a responsible person over the age of 60, DT: density, H_A: housing area.

\section{Household size effect}

The household size affects directly and negatively per-capita gas consumption (-0.493). This impact could be explained in two ways, firstly, by the fact that bigger households have lower incomes, and on the other side, large families obtain more internal heat from the number of household members. Also, the household size affects indirectly and negatively per-capita gas consumption through the housing area by -0.245 $\left(1.047^{*}-0.234\right)$. The household size has the biggest direct and indirect impact on the per-capita gas consumption in the department of Djelfa.

Education level impact

The education level affects positively the per-capita gas consumption in the department of Djelfa with a standardised value of 0.234 . The education level is positively correlated with $\mathrm{HRP}>60$ and it is not significantly correlated with the household size and room occupancy rate.
Table 9. Electricity Model Fit Indices.

\begin{tabular}{|l|c|c|c|c|c|c|}
\hline & df & $\chi^{2}$ & $\begin{array}{c}\text { Probabili- } \\
\text { ty level }\end{array}$ & $\begin{array}{c}\text { RM- } \\
\text { SEA }\end{array}$ & NFI & CFI \\
\hline $\begin{array}{l}\text { Electrici- } \\
\text { ty model }\end{array}$ & 11 & 6.352 & 0.849 & 0.057 & 0.980 & 1.000 \\
\hline
\end{tabular}

\section{Housing area impact}

Surprisingly, the housing area affects negatively the per-capita gas consumption in the department of Djelfa. This result could be explained based on the table above and the PCA (Fig. 6) where we can easily observe a concentration of largest housing in the arid and scattered zone where the number of subscribers linked to the gas network is the lowest. In other words, households located in the arid zone use gas cylinders for heating and cooking which explains this reversed logic.

Estimating elasticity of electricity consumption in the department of Djelfa

Fit indices

Table 9 demonstrates that the model satisfies all the fit indices and the figure below shows the direct impact of the variables on per-capita electricity consumption. The demonstrated paths are all significant at less than $0.001,0.05$ and 0.08 levels as shown in the table below.

Impact of the household size

The impact of the household size is also the greatest with only an indirect value of -0.86 through the housing area $\left(1.047^{*}-0.829\right)$. This could be explained by a lower income and the

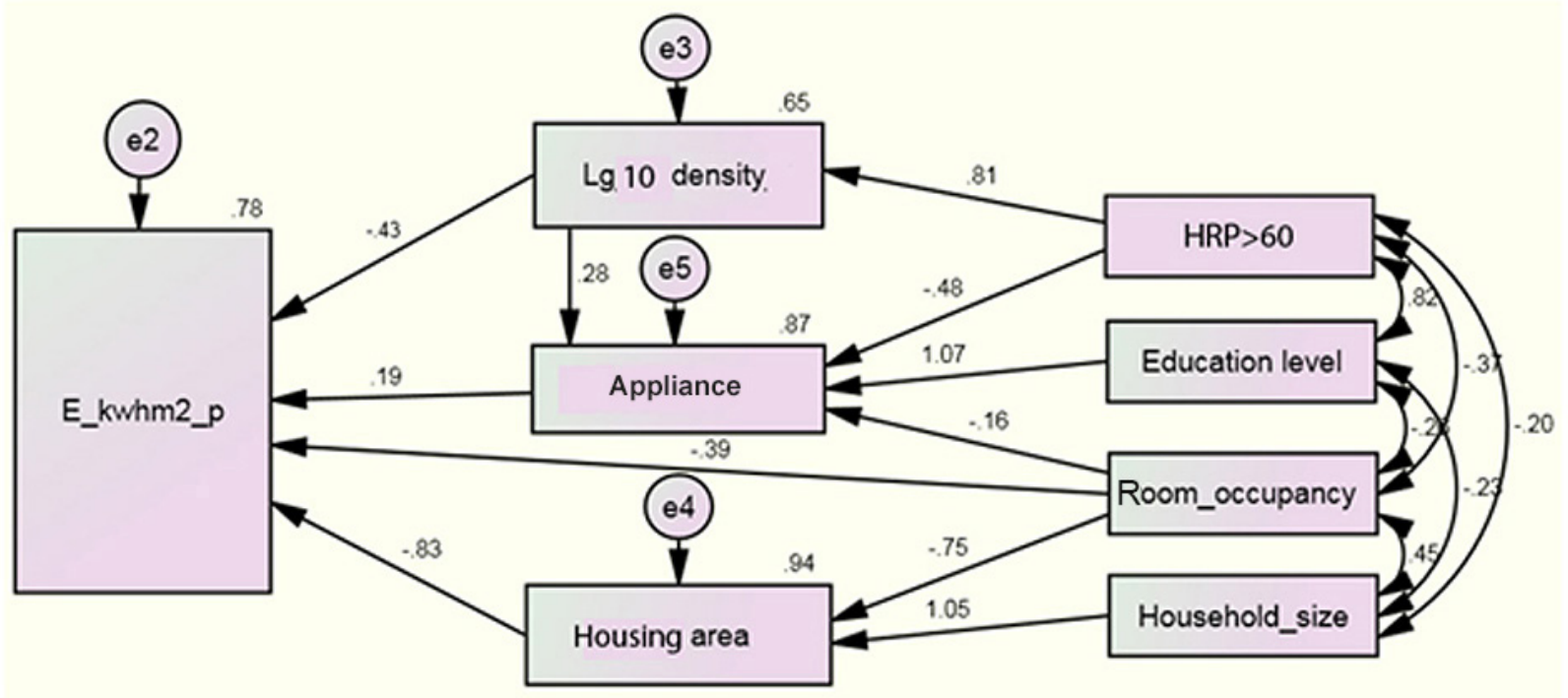

Fig. 11. Direct impact of variables on per-capita electricity consumption. 
Table 10. Path analysis: significance of direct impact.

\begin{tabular}{|l|c|c|c|c|}
\hline & & & Estimate & $P$ \\
\hline log 10 density & $\leftarrow$ & HRP>60 & .805 & *** \\
\hline appliance & $\leftarrow$ & log density & .275 & $.008^{* *}$ \\
\hline appliance & $\leftarrow$ & room occupancy & -.163 & $.014^{* *}$ \\
\hline appliance & $\leftarrow$ & education local & 1.070 & $* *$ \\
\hline appliance & $\leftarrow$ & HRP>60 & -.480 & $*$ *** \\
\hline housing area & $\leftarrow$ & room occupancy & -.745 & $*$ *** \\
\hline housing area & $\leftarrow$ & household size & -.829 & $*$ *** \\
\hline E_kwhm2_p & $\leftarrow$ & housing area & -.430 & $*$ \\
\hline E_kwhm2_p & $\leftarrow$ & log density & .194 & $.071^{*}$ \\
\hline E_kwhm2_p & $\leftarrow$ & appliance & -.395 & $* *$ \\
\hline E_kwhm2_p & $\leftarrow$ & room occupancy & & \\
\hline
\end{tabular}

***significant at 0.001 level

**significant at 0.05 level

*significant at 0.08 level

phenomenon of sharing electrical gadgets by household members.

Impact of the education level

As for the gas consumption, the education level affects positively per capita electricity consumption but indirectly through appliance ownership. An increase in the education level in households will result in the greater number of appliances at homes which induce more electricity consumption per capita.

\section{Impact of room occupancy}

The number of persons per room affects directly and negatively electricity consumption which could be explained by the fact that family members share their appliances and gadgets. And the indirect impact through appliance ownership and the housing area is positive and greatest than the direct impact $\left(0.163^{*}-0.194\right.$ with $\left.-0.745^{*}-0.829\right)$. The increasing room occupancy rate generates a decrease in appliance ownership and housing surfaces.

\section{Impact of HRP $>60$}

The household with a responsible person older than 60 has an indirect negative impact on electricity consumption through appliance ownership $\left(-0.48^{*} 0.19\right)$ and through the density $\left(0.81^{*}-0.43\right)$. Households with responsible persons have fewer appliances than younger households and as observed above, older households are concentrated mainly in the densest zone. The overall impact of older households remains negative on per capita energy consumption.

Impact of population density

Population density has a direct negative impact on per-capita electricity consumption $(-0.43)$. An increase in the density reduces the incidence of solar radiation which generates a decrease in cooling demand. Also, the density has a small indirect positive correlation through appliance ownership (0.0532). An increase in the density will generate a rise in appliance ownership which will increase per-capita electricity consumption. The overall impact of the density on electricity consumption is negative $(-0.376)$.

Impact of appliance ownership

Intuitively, the ownership of household appliances has a positive impact on per-capita electricity consumption with a value of 0.194 . This result confirms the tendency which links appliance ownership (TV, refrigerator, air conditioner and washing machine) to electricity consumption.

Table 11. Direct, indirect and total impact of variables on per-capita electricity consumption.

\begin{tabular}{|c|c|c|c|c|c|c|c|c|c|c|c|c|c|c|c|c|c|c|c|c|c|}
\hline \multirow[t]{2}{*}{ Effect } & \multicolumn{3}{|c|}{ Household size } & \multicolumn{3}{|c|}{ Education level } & \multicolumn{3}{|c|}{$\begin{array}{l}\text { Room occu- } \\
\text { pancy }\end{array}$} & \multicolumn{3}{|c|}{ HRP $>60$} & \multicolumn{3}{|c|}{ Log 10 density } & \multicolumn{3}{|c|}{ Appliance } & \multicolumn{3}{|c|}{ Housing area } \\
\hline & Dir & iir & tc & Dir & in- & tot & Dir & in- & tot & ir & $\operatorname{dir}$ & tot & ir & in- & tot & Dir & \begin{tabular}{|l|} 
in- \\
ir \\
\end{tabular} & t & ir & 1- & bt \\
\hline ensit & .000 & .0 & .000 & .000 & .000 & .000 & .000 & .000 & .0 & 805 & .000 & .80 & .00 & .000 & .000 & 00 & 000 & 1. & 00 & 0 & 000 \\
\hline & & & & & & & & & & & & -.2 & & & & & & & & & \\
\hline & .047 & .000 & 1.047 & .000 & .000 & .000 & -.745 & .000 & -.745 & .000 & .000 & .000 & .000 & .000 & .00 & |.000 & .00 & & .000 & & .0 \\
\hline $\mathrm{ec}^{*}$ & .000 & -.868 & -.868 & .000 & .207 & .207 & -.395 & .586 & .192 & .000 & .396 & -.396 & -430 & .053 & -.376 & .194 & 00 & 194 & -.829 & .000 & .829 \\
\hline
\end{tabular}

*Elec: per-capita electricity consumption $\left(\mathrm{kwh} / \mathrm{m}^{2}\right.$.y.capita). 


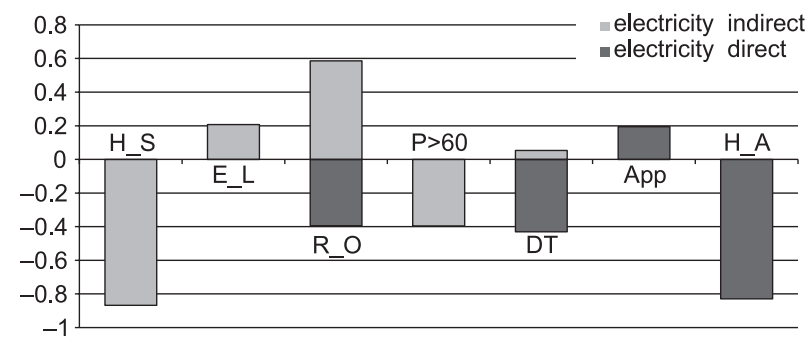

Fig. 12. Direct and indirect effect of variables on household electricity consumption. With: H_S: household size, E_L: education level, R_O: room occupancy, $\mathrm{HRP}>60$ : household with a responsible person over the age of 60, DT: density, App: appliance ownership, H_A: housing area.

\section{Impact of the housing area}

Surprisingly, in the department of Djelfa, the impact of the housing surface affects negatively and directly per-capita electricity consumption. It has the second most important impact after the household size. This result has a reversed logic in the scientific literature and it could be explained by the fact that biggest households are also concentrated in the arid and scattered zones which are less connected to the electricity network and this kind of household could use other independent energy sources like fuel oil or diesel. The second possible explanation is that the lower income in the arid and scattered zones induces less use of electricity. The third possible explanation could be ascribed to the effective use of housing surfaces.

\section{Conclusion \\ Overall impact of household, housing, density and appliance ownership variables on per-capita gas and electricity consumption in the department of Djelfa.}

In this work, a set of sensitivity analyses have been performed to understand the energy consumption of households in the department of Djelfa. Firstly, based on the PCA analysis, we have clustered municipalities according to their climate zone, population distribution, household, and housing variables. The diagnosis of the PCA performed indicates that there is a set of possible correlations which we have confirmed, based on bivariate correlations, and discussed the results according to the scientific literature. Finally, to be able to assess the elasticity of the

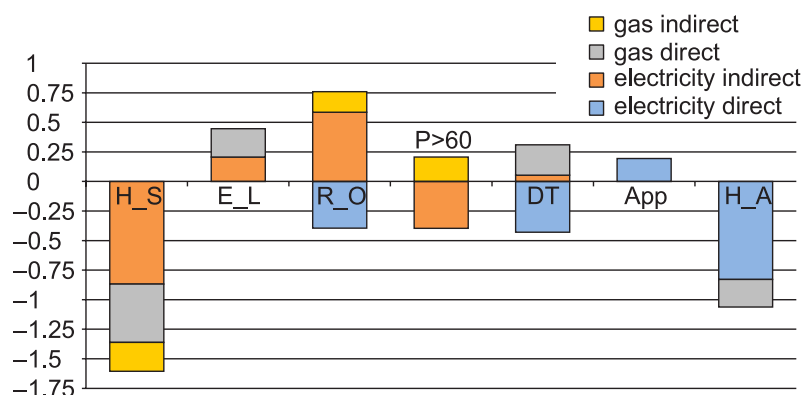

Fig. 13. Direct and indirect effect of variables on gas and electricity household consumption. With: H_S: household size, E_L: education level, R_O: room occupancy, HRP>60: household with a responsible person over the age of 60, DT: density, App: appliance ownership, H_A: housing area.

selected variables, a path analysis within a SEM was performed. It showed the impact of the household, housing, density (population distribution) and appliance ownership variables on per-capita electricity and gas consumption. The overall impact of all these variables indicates that an increasing household size is the first factor reducing the electricity and gas consumption followed by the housing surface and the density, room occupancy and older households. Besides, a higher education level and density affects positively, directly and indirectly per-capita gas and electricity consumption. An increase in room occupancy affects indirectly gas and electricity consumption, while older households increase indirectly the gas consumption. In SEM analysis, cooker ownership has no significant impact on gas consumption while the possession of other appliances (TV, air conditioner, refrigerator and washing machine) have a significant direct impact on per-capita electricity consumption.

For further research, the findings of this work draw our attention to the micro level of the analysis. Other factors could be explored, like the income, all the sources of energy used for heating, cooking and cooling in the municipalities which are not sufficiently linked to the gas and electricity network.

\section{References}

Alam M., Sathaye J., Barnes D., 1998. Urban household energy use in India: Efficiency and policy implications. Energy policy 26(11): 885-891.

Ali-Toudert F., Weidhaus J., 2017. Numerical assessment and optimization of a low-energy residential building for 
Mediterranean and Saharan climates using a pilot project in Algeria. Renewable Energy 101: 327-346.

APRUE 2010. Recueil de textes législatifs et réglementaires sur la maîtrise de l'énergie, retrieved from : www.aprue. org.dz/ (accessed: January 2017).

APRUE 2012. Final report, Consommation Energétique Finale de l'Algérie, Chiffres clés Année 2012. Retrieved from http:/ / www.aprue.org.dz/ (accessed: January 2017).

Baker K.J., Rylatt R.M., 2008. Improving the prediction of UK domestic energy-demand using annual consumption-data. Applied Energy 85(6): 475-482.

Bedir M., Hasselaar E., Itard L., 2013. Determinants of electricity consumption in Dutch dwellings. Energy and Buildings 58: 194-207.

Beerepoot M., Beerepoot N., 2007. Government regulation as an impetus for innovation: Evidence from energy performance regulation in the Dutch residential building sector. Energy Policy 35(10): 4812-4825.

Bouamama Wahiba, 2013. Au Sujet De La Politique D'efficacité Energétique En Algérie: Approche Systémique Pour Un Développement Durable. Cas De: Programme EcoBat Cnerib. Master's Thesis, University of Tlemcen.

Boukarta S., Berezowska E., 2017. Exploring the energy implication of urban density in residential buildings. Journal of Applied Engineering Sciences 7(1): 7-14. (accessed: 21 July 2017) doi:10.1515/jaes-2017-0001

Brounen D., Kok N., Quigley J.M., 2012. Residential energy use and conservation: Economics and demographics. European Economic Review 56(5): 931-945.

Carlson D.R., Matthews H.S., Bergés M., 2013. One size does not fit all: Averaged data on household electricity is inadequate for residential energy policy and decisions. Energy and Buildings 64: 132-144.

Carter A., Craigwell R., Moore W., 2011. Price reform and household demand for electricity. Journal of Policy Modeling 34(2): 242-252.

CDER, RETA. Website of the thermal regulation in Algeria. www.reta.cder.dz (accessed: January 2017)

Chen J., Wang X., Steemers K., 2013. A statistical analysis of a residential energy consumption survey study in Hangzhou, China. Energy and Buildings 66: 193-202.

Cramer J.C., Miller N., Craig P., Hackett B.M., Dietz T.M., Vine E.L., Kowalczyk D.J., 1985. Social and engineering determinants and their equity implications in residential electricity use. Energy 10(12): 1283-1291.

Dall'o' G., Galante A., Torri M., 2012. A methodology for the energy performance classification of residential building stock on an urban scale. Energy and Buildings 48: 211-219.

De VillaretF., 1995.Siècles de steppe, Jalons pour l'histoire de Djelfa, Centre de Documentation Saharienne, Ghardaia (Algérie).

De Groot E., Spiekman M., Opstelten I., (2008), Dutch research into user behaviour in relation to energy use of residences. In: 25 th PLEA Conference on Passive and Low Energy Architecture.

Derradji L., Boudali Errebai F., Amara M., Maoudj Y., Dhebri B., Chikh S., Mokhtari F., 2011. Etude expérimentale du comportement thermique d'une maison rurale à faible consommation d'énergie. In: 15 èmes Journées Internationales de Thermique, JITH2011, Tlemcen, Alegria.

Derradji L., Imessad K., Amara M., Errebai F.B., 2017. A study on residential energy requirement and the effect of the glazing on the optimum insulation thickness. Applied Thermal Engineering 112: 975-985.
DerradjiL., ImessadK., Boudali ErrebaiF., AmaraM., MaoudjY., MokhtariF., 2012. Etude de l'efficacité énergétique d'une maison économique en Algérie. In: 2 ème Congres de l'Association Marocaine de Thermique, Casablanca, Morocco.

Djelloul A., Draoui B., Moummi N., 2013. Simulation du comportement énergétique des bâtiments résidentiels au sud algérien. Courrier du Savoir 17: 113-119.

DTR C3.2., 2004. Règlement Thermique des Bâtiments d'Habitation e Règles de Calcul des Déperditions Calorifiques, Fascicule 1, Document Technique Réglementaire, Ministère de l'habitat et de l'urbanisme, CNERIB, Alger.

DTR C3.4., 2004. Règlement Thermique des Bâtiments d'Habitation et Règles de Calcul des Apports Calorifiques des Bâtiments, Fascicule 2, Document Technique Réglementaire, Ministère de l'habitat et de l'urbanisme, CNERIB, Alger.

Fanger P., 1972. Thermal comfort: Analysis and applications in environmental engineering. McGraw-Hill, New York.

Field A., 2009. Discovering statistics using SPSS. Sage publications.

Ghasemi A., Zahediasl S., 2012. Normality tests for statistical analysis: A guide for non-statisticians. International Journal of Endocrinology and Metabolism 10(2): 486.

Giz, 2015. Guide Pour Une Construction Eco-Energétique En Algérie.

Gram-Hanssen K., Kofod C., Petersen K.N., 2004. Different everyday lives: Different patterns of electricity use. In 2004 ACEEE Summer study on energy efficiency in buildings, pp. 1-13.

Guerra Santin O., 2010. Actual energy consumption in dwellings: The effect of energy performance regulations and occupant behaviour. Sustainable Urban Areas 33.

Haas R., Auer H., Biermayr P., 1998. The impact of consumer behaviour on residential energy demand for space heating. Energy and Buildings 27: 195-205.

Halvorsen B., Larsen B.M., 2001. Norwegian residential electricity demand - a microeconomic assessment of the growth from 1976 to 1993. Energy Policy 29(3): 227-236.

Hamiche A.M., Stambouli A.B., Flazi S., 2015. A review on the water and energy sectors in Algeria: Current forecasts, scenario and sustainability issues. Renewable and Sustainable Energy Reviews 41: 261-276.

Hammad K., Saeed T., Sharawi H.A., 2014. Factors affecting fuel consumption in household cooking in El-Salam locality, South Kordofan State, Sudan. The 5th Annual Conference - Agricultural and Veterinary Research.

Harold J., Lyons S., Cullinan J., 2015. The determinants of residential gas demand in Ireland. Energy Economics 51: 475-483.

Himri Y., Malik A.S., Stambouli A.B., Himri S., Draoui B. 2009. Review and use of the Algerian renewable energy for sustainable development. Renewable and Sustainable Energy Reviews 13(6-7): 1584-1591.

Holden E., and Norland I.T.,2005. Three challenges for the compact city as a sustainable urban form: Household consumption of energy and transport in eight residential areas in the Greater Oslo Region. Urban Studies 42 (12): 2145.

Hooper D., Coughlan J., Mullen M., 2008. Structural equation modelling: Guidelines for determining model fit. Electronic Journal of Business Research Methods 6(1): 53-60.

Hui Sam C.,M., 2001. Low energy building design in high density urban cities. Renewable Energy 24: 627-640. 
Hu L.T., Bentler P.M., 1999. Cutoff criteria for fit indexes in covariance structure analysis: Conventional criteria versus new alternatives. Structural Equation Modeling: A Multidisciplinary Journal 6(1): 1-55.

Iacobucci D., 2010. Structural equations modeling: Fit indices, sample size, and advanced topics. Journal of Consumer Psychology 20(1): 90-98.

Imessad K., Derradji L., Messaoudene N.A., Mokhtari F., Chenak A., Kharchi R., 2014. Impact of passive cooling techniques on energy demand for residential buildings in a Mediterranean climate. Renewable energy 71: 589-597.

JO. Journal Officiel, République démocratique algérienne et populaire, 2017. www.joradp.dz.

Jones R.V., Fuertes A., Lomas K.J., 2015. The socio-economic, dwelling and appliance related factors affecting electricity consumption in domestic buildings. Renewable and Sustainable Energy Reviews 43: 901-917.

Karamizadeh S., Abdullah S.M., Manaf A.A., Zamani M., Hooman A., 2013. An overview of principal component analysis. Journal of Signal and Information Processing 4(03): 173.

Kavousian A., Rajagopal R., Fischer M., 2013. Determinants of residential electricity consumption: Using smart meter data to examine the effect of climate, building characteristics, appliance stock, and occupants'behavior. Energy 55: 184-194.

Kelly S., 2011. Do homes that are more energy efficient consume less energy?: A structural equation model of the English residential sector. Energy 36(9): 5610-5620.

Kim H.Y., 2013. Statistical notes for clinical researchers: Assessing normal distribution (2) using skewness and kurtosis. Restorative Dentistry \& Endodontics 38(1): 52-54.

Lariviere I., Lafrance G., 1999. Modelling the electricity consumption of cities: Effect of urban density. Energy economics 21(1): 53-66.

Leahy E., Lyons S., 2010. Energy use and appliance ownership in Ireland. Energy Policy 38(8): 4265-4279.

Liao H.C., Chang T.F., 2002. Space-heating and water-heating energy demands of the aged in the US. Energy Economics 24(3): 267-284.

Lindén A.L., Carlsson-Kanyama A., Eriksson B., 2006. Efficient and inefficient aspects of residential energy behaviour: What are the policy instruments for change? Energy policy 34(14): 1918-1927.

McLoughlin F., Duffy A., Conlon M., 2012. Characterising domestic electricity consumption patterns by dwelling and occupant socio-economic variables: An Irish case study. Energy and Buildings 48: 240-248.

Ndiaye D., Gabriel K., 2011. Principal component analysis of the electricity consumption in residential dwellings. Energy and Buildings 43(2): 446-453.

Nielsen L., 1993. How to get the birds in the bush into your hand: Results from a Danish research project on electricity savings. Energy Policy 21(11): 1133-1144.

ONS (Office for National Statistic), 2008. 2008's census data.

Öztuna D., Elhan A.H., Tüccar E., 2006. Investigation of four different normality tests in terms of type 1 error rate and power under different distributions. Turkish Journal of Medical Sciences 36(3): 171-176.

Ouedraogo B., 2006. Household energy preferences for cooking in urban Ouagadougou, Burkina Faso. Energy Policy 34(18): 3787-3795.

Ouyang J., Hokao K., 2009. Energy-saving potential by improving occupants'behavior in urban residential sector in Hangzhou City, China. Energy and Buildings 41(7): 711-720.

Owen J.A., 2014. Principal Component Analysis: Data reduction and simplification. McNair Scholars Research Journal 1(1): 2.

Parti M., Parti C., 1980. The total and appliance-specific conditional demand for electricity in the household sector. The Bell Journal of Economics 309-321.

Salat S., Labbé F., 2011. Les villes et les formes: sur l'urbanisme durable. Hermann.

Santamouris M., Kapsis K., Korres D., Livada I., Pavlou C., Assimakopoulos M.N., 2007. On the relation between the energy and social characteristics of the residential sector. Energy and Buildings 39(8): 893-905.

Sénit C.A., 2008. L'efficacité énergétique dans le secteur résidentiel: Une analyse des politiques des pays du Sud et de l'Est de la Méditerranée. IIddri, Idées pour le débat 14.

Schreiber J.B., Nora A., Stage F.K., Barlow E.A., King J., 2006. Reporting structural equation modeling and confirmatory factor analysis results: A review. The Journal of Educational Research 99(6): 323-338.

Sonderegger R.C., 1978. Movers and stayers: The resident's contribution to variation across houses in energy consumption for space heating. Energy and Buildings 1(3): 313-324.

Sonelgaz, 2013. Yearly energy consumption of the department of Djelfa.

Steadman P., 1979. Energy and patterns of land use. In: Watson D. (ed.), Energy conservation through building design. McGraw-Hill, New York: 246-260.

Subrémon H., 2009. Habiter avec l'énergie. Pour une anthropologie sensible de la consommation d'énergie. Doctoral dissertation, Université de Nanterre-Paris X.

Tso G.K., Yau K.K., 2007. Predicting electricity energy consumption: A comparison of regression analysis, decision tree and neural networks. Energy 32(9): 1761-1768.

VandeWeghe J.R., Kennedy C., 2007. A spatial analysis of residential greenhouse gas emissions in the Toronto census metropolitan area. Journal of Industrial Ecology 11(2): 133-144.

Wiesmann D., Azevedo I.L., Ferrão P., Fernández J.E., 2011. Residential electricity consumption in Portugal: Findings from top-down and bottom-up models. Energy Policy 39(5): 2772-2779.

Yohanis Y.G., Mondol J.D., Wright A., Norton B., 2008. Real-life energy use in the UK: How occupancy and dwelling characteristics affect domestic electricity use. Energy and Buildings 40(6): 1053-1059.

Zhou S., Teng F., 2013. Estimation of urban residential electricity demand in China using household survey data. Energy Policy 61: 394-402. 